\title{
Taxon-specific multiplex-PCR for quick, easy, and accurate identification of encyrtid and aphelinid parasitoid species attacking soft scale insects in California citrus groves
}

\author{
Paul F. Rugman-Jones • Lisa D. Forster • \\ Emilio Guerrieri • Robert F. Luck • Joseph G. Morse • \\ Maurilia M. Monti · Richard Stouthamer
}

Received: 6 August 2010/ Accepted: 25 October 2010/Published online: 5 November 2010

(C) The Author(s) 2010. This article is published with open access at Springerlink.com

\begin{abstract}
Citricola scale, Coccus pseudomagnoliarum Kuwana (Hemiptera: Coccidae), is a serious pest of citrus in California's San Joaquin Valley, but not in southern California where a complex of Metaphycus spp. Mercet (Hymenoptera: Encyrtidae) suppress it. This has created interest in using these (and other Metaphycus) species for biological control in the San Joaquin Valley. A critical step in assessing an organism's potential for biological control is the ability to accurately identify it. For Metaphycus spp., this currently requires slide mounted adult specimens and expert taxonomic knowledge. We present a simple, quick and accurate method to identify any life stage of the ten major parasitoids of soft scales in California citrus, based on amplification of ribosomal DNA, using the polymerase chain reaction (PCR). Three multiplex-PCR protocols amplify products of taxon-specific sizes, allowing direct diagnosis of taxa
\end{abstract}

Handling Editor: Torsten Meiners

P. F. Rugman-Jones $(\bowtie) \cdot$ L. D. Forster

R. F. Luck - J. G. Morse - R. Stouthamer

Department of Entomology, University of California,

Riverside, CA 92521, USA

e-mail: paul.rugman-jones@ucr.edu

E. Guerrieri · M. M. Monti

Istituto per la Protezione delle Piante, Consiglio

Nazionale delle Ricerche, Via Università 133,

80055 Portici, NA, Italy accommodated by the PCR, and reducing identification time to a fraction of that of existing methods.

Keywords Hymenoptera - Metaphycus .

Coccophagus $\cdot$ Microterys $\cdot$ Citricola scale $\cdot$ rDNA

\section{Introduction}

In recent years, citricola scale, Coccus pseudomagnoliarum Kuwana (Hemiptera: Coccidae), has re-emerged as a serious pest of citrus in central California's San Joaquin Valley. Having once been a major pest of California citrus (Quayle 1938), citricola scale was incidentally reduced to a minor pest following the advent of broad-spectrum insecticide use, in the late 1940s, for the control of armored scales (Kennet 1988). However, the re-emergence of citricola scale as a pest in the San Joaquin Valley coincided with the evolution of resistance by the economically important armored scales Aonidiella aurantii Maskell and A. citrina Coquillet to broad-spectrum organophosphate and carbamate insecticides (Grafton-Cardwell 1994), and a subsequent shift to biological control methods to suppress armored scale (Luck et al. 1997; UCIPM 2009a). In contrast, citricola scale remains extremely rare in southern California citrus groves (Morse et al. 2006; Kapranas et al. 2007; UCIPM 2009b), following its fortuitous demise in the 1930s, when several parasitoids were introduced to combat black scale, Saissetia oleae Olivier (Bartlett 1953, 1978). 
The stark difference in the occurrence of citricola scale between the two regions has been largely credited to a relative paucity in the diversity and abundance of encyrtid species (Hymenoptera: Encyrtidae) in the San Joaquin Valley, particularly those in the genus Metaphycus Mercet (Lampson and Morse 1992; Bernal et al. 2001; Kapranas et al. 2007). As primary endoparasitoids, mainly of soft or armored scales, species of Metaphycus play a crucial role in the natural regulation of their hosts (Guerrieri and Noyes 2000). In the San Joaquin Valley, only two Metaphycus species are commonly associated with citricola scale: M. helvolus (Compere) and M. luteolus (Timberlake). However, together they account for $<14 \%$ of total scale parasitism and the overwhelming majority of scale parasitism in that region $(83.9 \%)$ is attributed to the aphelinid autoparasitoid Coccophagus lycimnia (Walker) (Bernal et al. 2001). In contrast, in southern California, a recent survey of the parasitoid complex associated with brown soft scale, Coccus hesperidum L. (an alternative host for parasitoids of citricola scale), identified four Metaphycus species, M. helvolus, M. luteolus, M. stanleyi (Compere), and M. angustifrons (Compere), which together accounted for $75 \%$ of scale parasitism (Kapranas et al. 2007). Another encyrtid, Microterys nietneri (Motschulsky), accounted for a further $7 \%$ of scale parasitism, but Coccophagus spp. (abundance of individual species was not determined) accounted for only $11 \%$ of total scale parasitism (Kapranas et al. 2007). It is thought that the complex of Metaphycus spp. exercises complete control over citricola scale in southern California (UCIPM 2009b) creating interest in the possibility of using the additional Metaphycus species in an augmentative release program in the San Joaquin Valley. Interestingly, although $M$. angustifrons was found to be by far the most abundant parasitoid of brown soft scale in southern California, this was actually a new record of establishment in California for this species. However, $M$. angustifrons and M. stanleyi are morphologically very similar (indeed males of the two species are acknowledged as inseparable; Kapranas et al. 2007) and it seems highly likely that $M$. angustifrons has previously been misidentified.

A further species of Metaphycus that has attracted the attention of citrus researchers in California is M. flavus (Howard) (Bernal et al. 1999; Schweizer et al. 2002, 2003). This species was collected in 1996 from citricola scale at Kozan, Turkey, and has since been introduced to central California's San Joaquin Valley for the biological control of citricola scale (Bernal et al. 1999; Schweizer et al. 2002), and to southern California orchards for the control of black scale (Schweizer et al. 2003). However, it is unknown whether this species has established in either region, at least in part because it is morphologically indistinguishable from the native $M$. luteolus. In their authoritative revision of European species of Metaphycus, Guerrieri and Noyes (2000) concede that the two species may actually be synonymous.

A critical step in assessing an organism's potential for biological control is the ability to accurately identify it (Bigler et al. 2005). This can be problematic if definitive morphological characters are elusive or difficult to interpret. The identification of scale parasitoids is hampered by their small size (typically less than $2 \mathrm{~mm}$ in length), and whilst several diagnostic keys based on morphological characters are in circulation, in most cases, high quality, expertly prepared, slide-mounted specimens are requisite for reliable identification. For example, accurate identification of some Metaphycus spp. requires slide preparations that include a dissection of the specimen's mouthparts (see Guerrieri and Noyes 2000). Thus, traditional methods of identifying soft scale parasitoids are time consuming and require specialized knowledge. Furthermore, morphological keys rely on characters of adult specimens and cannot be used to reliably identify immature life stages.

Over the last decade, the use of molecular techniques to identify species has increasingly been advocated in genera that lack definitive morphological characters. Typically, this has involved the use of the polymerase chain reaction (PCR) to amplify short stretches of DNA, which are then characterized by secondary experimental methods such as sequencing or digestion with restriction endonucleases (e.g., Stouthamer et al. 1999; Rugman-Jones et al. 2006, 2009a). However, such secondary methods require further investment of time and money. Thus, methods that allow direct interpretation of the product of the PCR reaction are favorable. In situations where a specimen is likely to be only one of a relatively small number of species, taxon-specific multiplex-PCR offers one solution. This technique involves the use of one PCR primer located in a region shared by several taxa (a universal primer) alongside several 
opposing primers, each of which lies in a region that is specific to only one of the taxa under consideration, and which when it amplifies, produces a PCR product of a size that is unique to that taxon. As a result, taxa can be identified directly following gel electrophoresis of the PCR product (e.g., Cornel et al. 1996; Fritz et al. 2004; Gariepy et al. 2005; Rugman-Jones et al. 2009b).

Here we present a molecular identification method based on multiplex-PCR, enabling rapid and reliable identification of ten parasitoid species (from three genera), which are (Kapranas et al. 2007), or through augmentative releases may become (Bernal et al. 1999; Schweizer et al. 2002, 2003), part of the complex of parasitoids attacking soft scales in California citrus groves: Metaphycus luteolus, M. stanleyi (M. swirskii), $M$ angustifrons, M. helvolus, M. flavus, Microterys nietneri, Coccophagus cowperi (Girault), C. lycimnia, C. rusti (Compere), and C. semicircularis (Forster). Of these, M. luteolus is the only California native, the others having been originally imported into California for release against various soft scale species (Bartlett 1978; Daane et al. 1991; Lampson and Morse 1992; Bernal et al. 1999). This work seeks to provide a quick and accurate means to identify the complex of parasitoid species currently attacking soft scales in California citrus, and to monitor the success in the San Joaquin Valley of future augmentative releases of parasitoids introduced from southern California against citricola scale.

\section{Materials and methods}

Origin of parasitoids

Four of the five Metaphycus species used in this study were taken from separate cultures maintained on brown soft scale at the University of California, Riverside (UCR), USA. Bernal et al. (1999) gave original collection details for the cultures of $M$. luteolus, M. stanleyi, and M. flavus. The M. angustifrons culture originated from wasps collected at the Citrus Heritage Park, Riverside, Riverside Co., California, USA (N3 $\left.{ }^{\circ} 53.534 \mathrm{~W} 117^{\circ} 25.278\right)$ on 4 March 2004. The fifth Metaphycus species, M. helvolus, was identified from field-collected material (Kapranas et al. 2007) during testing of our multiplex-PCR methods (see below). The four species of
Coccophagus were identified from this same fieldcollected material. Specimens of Microterys nietneri were taken from a culture maintained on brown soft scale at UCR, which originated from wasps collected at Rancho Pauma Granite, Pauma Vista, San Diego Co., California, USA (N33 ${ }^{\circ} 20.105$ W116 58.483$)$ on 10 May 2004.

DNA extraction, amplification and sequencing

DNA was extracted from intact individual wasps using the EDNA HiSpEx ${ }^{\mathrm{TM}}$ Tissue Kit (Fisher Biotech, Wembley, Australia) according to the manufacturer's guidelines for extracting from $1 \mathrm{~mm}^{3}$ tissue. For each species, the polymerase chain reaction (PCR) was used to amplify separately two stretches of nuclear ribosomal DNA (rDNA): a section of the D2 expansion region of $28 \mathrm{~S}$, and the internal transcribed spacer 2 (ITS2). PCR was performed in $25 \mu \mathrm{l}$ reactions containing $1 \times$ ThermoPol PCR buffer (New England BioLabs, Ipswich, MA, USA), $0.2 \mathrm{mM}$ dATP, $0.2 \mathrm{mM}$ dCTP, $0.2 \mathrm{mM}$ dGTP, $0.4 \mathrm{mM}$ dUTP, $2 \mu \mathrm{l}$ BSA (NEB), $1 \mathrm{U} \mathrm{Taq}$ polymerase (NEB), and $0.2 \mu \mathrm{M}$ each of the primers: ITS2-forward (5'-TGTGAACTGCAGGACACATG-3'; Campbell et al. 1993) and ITS4 (5'-TCCTCCGCTTATTGATATGC-3'; White et al. 1990) for ITS2; and D2-CF (5'-CGTGTTGCTTGA TAGTGCAGC-3') and D2-CR (5'-TTGGTCCGTGT TTCAAGACGGG-3'; Campbell et al. 1993, 2000) for 28S. Amplifications were performed in a Mastercycler $^{\circledR}$ ep gradient $S$ thermocycler (Eppendorf North America Inc., New York, NY, USA) with an initial denaturing step at $95^{\circ} \mathrm{C}$ for $3 \mathrm{~min}$, followed by 38 cycles of $94^{\circ} \mathrm{C}$ for $45 \mathrm{~s}, 55^{\circ} \mathrm{C}$ for $30 \mathrm{~s}, 72^{\circ} \mathrm{C}$ for $1 \mathrm{~min}$ $30 \mathrm{~s}$, and a final extension of $3 \mathrm{~min}$ at $72^{\circ} \mathrm{C}$. The presence of amplified products was confirmed by gel electrophoresis and PCR products were cleaned using the Wizard $^{\circledR}$ PCR Preps DNA purification kit (Promega, Madison, WI, USA) and direct-sequenced in both directions at the University of California Riverside Genomics Institute, Core Instrumentation Facility using an Applied Biosystems 3730 DNA analyzer with a Big-Dye V3.1 ${ }^{\circledR}$ kit (Applied Biosystems, Foster City, CA, USA). For most species, sequences were obtained for at least eight specimens, including three specimens from each of the cultures held at UCR (see above) and at least five specimens from field-collected material (see below). Exceptions to this were M. flavus and Microterys nietneri, which 
were not detected in the field and therefore were represented only by the three culture specimens. Sequences were aligned manually in BioEdit version 7.0.5.3 (Hall 1999) and representative sequences were deposited in GenBank $^{\circledR}$ (Benson et al. 2008). For each 'genetic' species, several intact specimens (from the field-collected 'test' material; see below) were retrieved from the DNA extractions and species identity was confirmed using available keys (Compere 1931, 1940; Annecke and Mynhardt 1971, 1972, 1981; Guerrieri and Noyes 2000) and by comparing the specimens with the types (where available), or with authoritatively identified specimens housed in the collections of the Natural History Museum (NHM, London) and of the Department of Agricultural Entomology and Zoology (DEZA), University of Naples (Portici, Italy). Voucher specimens are deposited in the Entomology Museum at UCR, in the NHM and in DEZA.

\section{Multiplex-PCR design}

Taxon-specific PCR primers were designed for three separate multiplex-PCRs (one genus-specific [based on $28 \mathrm{~S}$ sequences], and two species-specific [based on ITS2 sequences]) with the aid of Primer3 v.0.4.0 (Rozen and Skaletsky 2000) using the following criteria: (1) reverse primers should work with a common forward primer; (2) at least one nucleotide at the $3^{\prime}$ end of the primer must be unique to one target taxon in the alignment; (3) complementarity between primers should be minimal; (4) they should have similar melting temperatures (can be manipulated by substituting nucleotides at the $5^{\prime}$ end); and (5) they should produce a PCR product of a unique size for each included taxon, which can be readily distinguished using standard agarose gel electrophoresis. The specificity of several primers for each group of taxa was tested individually and in
multiplex-PCR against all included taxa, identifying a set of primers which gave the best combination of the desired characteristics (Tables 1,2). The specificity of each of the two species-specific multiplexPCRs was also tested against all the species included in the other to determine if false positives were produced (i.e., the Metaphycus spp. multiplex-PCR was tested against specimens of all four Coccophagus species, and vice versa).

\section{Multiplex-PCR conditions}

In each multiplex-PCR, DNA from individual wasps was amplified in $25 \mu \mathrm{l}$ reactions containing $1 \times$ ThermoPol buffer (NEB), $0.2 \mathrm{mM}$ dATP, $0.2 \mathrm{mM}$ dCTP, $0.2 \mathrm{mM}$ dGTP, $0.4 \mathrm{mM}$ dUTP, $2 \mu \mathrm{l}$ BSA (NEB), $0.2 \mu \mathrm{M}$ each primer (Tables 1, 2), $1 \mathrm{U}$ Taq polymerase (NEB), and $2 \mu$ template DNA (concentration undetermined). Amplification was performed in a Mastercycler ${ }^{\circledR}$ ep gradient $S$ thermocycler (Eppendorf North America, Inc.). The thermocycler profile for the three multiplex-PCRs was identical: an initial denaturing at $95^{\circ} \mathrm{C}$ for $3 \mathrm{~min}$ followed by 35 cycles of $94^{\circ} \mathrm{C}$ for $30 \mathrm{~s}, 57^{\circ} \mathrm{C}$ for $30 \mathrm{~s}, 72^{\circ} \mathrm{C}$ for $1 \mathrm{~min}$, and a final extension of $3 \mathrm{~min}$ at $72^{\circ} \mathrm{C}$. Following amplification, $5 \mu \mathrm{l}$ of each PCR product was visualized by electrophoresis on $1.5 \%$ agarose gels stained with ethidium bromide. Gels were run for $1.5 \mathrm{~h}$ at a voltage of $4.5 \mathrm{~V} \mathrm{~cm}^{-1}$ to ensure ample separation of the different sized bands.

Confirmation of morphological identifications of adult specimens using the species-specific multiplex-PCRs

The respective species-specific multiplex-PCR was used to identify specimens collected and preserved in 95\% ethanol between February 2004 and March 2006 from several southern California citrus groves. These

Table 1 Multiplex-PCR primers for identification of parasitoids to genus based on amplification of 28S rDNA

\begin{tabular}{lllr}
\hline Taxon & Primer name & Primer sequence & PCR product (bp) \\
\hline & MMC uni-F & $5^{\prime}$-CCGTGAGGGAAAGTTGAAAA-3' & 206 \\
Coccophagus & Coc-R & $5^{\prime}$-GAAGTGCACGTCGACCAC-3' & $\sim 530$ \\
Metaphycus & Met-R & $5^{\prime}$-TCCTGAAAGTACCCAAAGCAAA-3' & 277 \\
Microterys nietneri & Mic-R & $5^{\prime}$-GTCTACCGTACGAGCCTTGG-3' & \\
\hline
\end{tabular}


Table 2 Species-specific multiplex-PCR primers for identification of species of (a) Metaphycus and (b) Coccophagus based on amplification of ITS2 rDNA

\begin{tabular}{|c|c|c|c|}
\hline Taxon & Primer name & Primer sequence & PCR product (bp) \\
\hline \multicolumn{4}{|l|}{ (a) Metaphycus spp. } \\
\hline & M.uni-F & 5'-GGCTGAGGGTCGTTCSATAA-3' & \\
\hline M. angustifrons & ang-R1 & 5'-GCGTTCGAACACGAATTGTA-3' & 184 \\
\hline M. luteolus & lut-R3 & 5'-GTGCCATGAAACAACCAGAG-3' & 638 \\
\hline M. flavus & fla-R2 & 5'-CACAACAACACAGCACAGCA-3' & 531 \\
\hline M. stanleyi (M. swirskii) & sta-R1 & $5^{\prime}$-ACCACAAATTGGACGAGAGG-3' & 323 \\
\hline M. helvolus & hel-R1 & 5'-GCTCAGGCTTTCGCTGTC-3' & 75 \\
\hline Microterys nietneri $^{\mathrm{a}}$ & Mic-R1 & 5'-TTCGAGCGAGTGAGTGAGTG-3' & 671 \\
\hline \multicolumn{4}{|l|}{ (b) Coccophagus spp. } \\
\hline & C.uni-F & 5'-GACATTTCGAACGCACATTG-3' & \\
\hline C. cowperi & cow-R1 & 5'-AGCCAATTCGCTCGTTAGAC-3' & 109 \\
\hline C. lycimnia & lyc-R2 & 5'-GGCGTTTTAAAATAAACGCAAG- $3^{\prime}$ & 388 \\
\hline C. rusti & rus-R2 & 5'-CGCGTTGTTACCTTCCTTCT-3' & 183 \\
\hline C. semicircularis & sem-R2 & 5'-ACGAGCGTACTCAACTGCTG-3' & 495 \\
\hline
\end{tabular}

${ }^{a}$ Inclusion of the primer for Microterys nietneri is optional

specimens were collected as part of a survey of parasitoids of brown soft scale carried out by Kapranas et al. (2007). The material included 347 batch-reared Metaphycus individuals, omitted from their abundance data, but tentatively identified to species based on morphology, as well as 77 specimens of Coccophagus spp. identified only to genus (see Kapranas et al. 2007). The quality of the DNA extraction of any specimen that failed to produce a multiplex-PCR product was assessed by attempting to amplify the $28 \mathrm{~S}$ and ITS2 regions as above.

Parasitoid species diagnosis from parasitized host scales

Current morphology-based identification methods only work with adult wasps, and thus require "rearing out" of the parasitoids from their hosts prior to identification. Thus, if time and space is of the essence, it would be beneficial if parasitoids could be identified from the host scale material (i.e. prior to their emergence). Molecular-based identification offers this potential. A colony of brown soft scales on a single Yucca recurvifolia Salisbury leaf was isolated with a $M$. luteolus population allowing four days for the females to parasitize the scales. Immediately following that period, the Yucca leaf was isolated, preventing further parasitism, and five scales were collected at random. Two days later, another five scales were collected. At such an early stage of parasitoid development in these two collections (i.e., 1-6 days), it was impossible to definitively tell if a scale was parasitized or not. However, a further two days later (eight days after initial exposure to the parasitoids), larvae could be seen within the host scales under a dissecting microscope, and a further sample of five parasitized scales was collected. A final collection of five scales containing visible pupae was made on day 10. DNA was extracted from intact individual scales as described for the parasitoids, and tested using the Metaphycus species-specific multiplex-PCR. A second test was performed with scales exposed separately to $M$. angustifrons and $M$. stanleyi, but parasitized scales were collected only once (after eight days, when larvae were visible).

\section{Results}

As expected, 28S rDNA sequences (GenBank accessions HM856874-856887) were highly conserved within species. Only $C$. rusti, showed any intraspecific variation in this region. Sequences of ITS2 were slightly more variable, but variation was almost exclusively restricted to microsatellite repeats 
(GenBank accessions HM856888-856901). The one exception to this was $C$. semicircularis in which we found two different ITS2 sequences differing from each other by one insertion (nucleotide position 412) and two substitutions (nucleotide position 141-142). The DNA sequences obtained for the 28S and ITS2 regions of each species led to the design of three sets of taxon-specific multiplex-PCR primers: one for identification of specimens to genus (based on 28S; Table 1), and one set each for identification of species of Metaphycus and Coccophagus, respectively (based on ITS2; Table 2). Authoritative morphological identification confirmed the specific identity of specimens of nine of the ten parasitoid species. However, both the UCR colony, and specimens from the field that were initially thought to be Metaphycus stanleyi, actually keyed out as M. swirskii Annecke \& Mynhardt. Each multiplex-PCR successfully amplified the DNA of each included taxon, yielding PCR products of characteristic (and hence diagnostic) taxon-specific sizes (Figs. 1, 2, 3). Furthermore, no false positive bands were produced when the Coccophagus spp. were tested with the Metaphycus spp. multiplex-PCR, and vice versa (results not shown).

Use of the Metaphycus spp. multiplex-PCR to diagnose specimens previously identified using morphological methods found that many specimens were incorrectly identified using those morphological methods (Table 3). While molecular diagnoses concurred that females of M. luteolus and M. stanleyi had

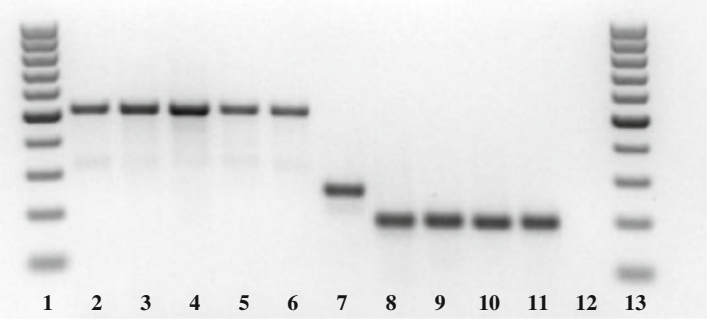

Fig. 1 Visualization of the $28 \mathrm{~S}$ multiplex-PCR products of the complex of ten parasitoid species attacking soft scales (Hemiptera: Coccidae) in California citrus groves. PCR products were electrophoresed on a $1.5 \%$ agarose gel. Lane 1, 100 bp DNA size standard (Fermentas, Inc., Glen Burnie, MD); lane 2, Metaphycus angustifrons; lane 3, M. luteolus; lane 4, M. stanleyi; lane 5, M. helvolus; lane 6, M. flavus; lane 7, Microterys nietneri; lane 8, Coccophagus semicircularis; lane 9, C. lycymnia; lane 10, C. rusti; lane 11, C. cowperi; lane 12 , no template control; lane $13,100 \mathrm{bp}$ DNA size standard

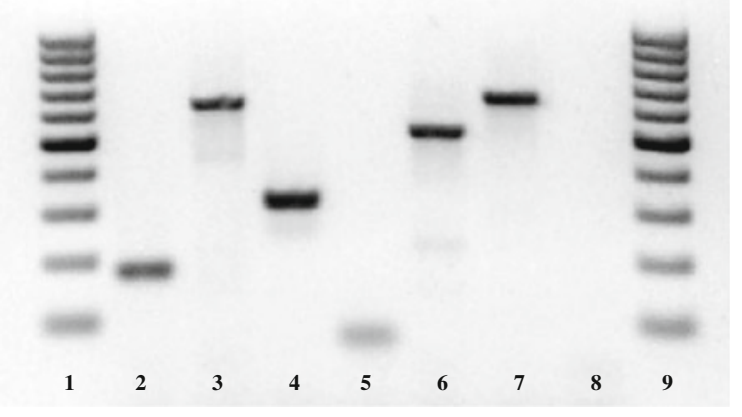

Fig. 2 Visualization of the Metaphycus spp. multiplex-PCR products following electrophoresis on a $1.5 \%$ agarose gel. Lane 1, 100 bp DNA size standard (Fermentas); lane 2, M. angustifrons; lane 3, M. luteolus; lane 4, M. stanleyi; lane 5, M. helvolus; lane 6, M. flavus; lane 7, Microterys nietneri; lane 8, no template control; lane 9, 100 bp DNA size standard

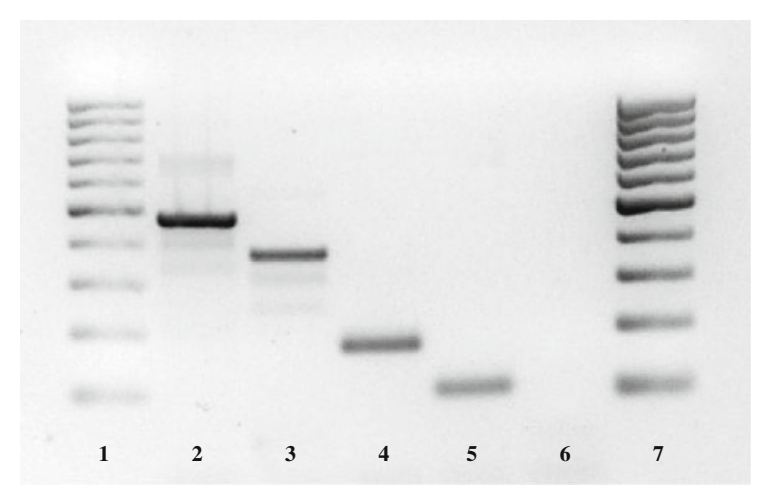

Fig. 3 Visualization of the Coccophagus spp. multiplex-PCR following electrophoresis on a $1.5 \%$ agarose gel. Lane 1, 100 bp DNA size standard (Fermentas); lane 2, C. semicircularis; lane 3, C. lycymnia; lane 4, C. rusti; lane 5, C. cowperi; lane 6, no template control; lane 7, 100 bp DNA size standard

consistently been correctly identified using morphology (although M. stanleyi actually appears to be M. swirskii, see above), the morphological identifications of males of these two species were not so reliable, with $16 \%$ and $63 \%$ of specimens identified as male $M$. luteolus and $M$. stanleyi respectively, actually being found to be M. angustifrons (Table 3). A further $13 \%$ of specimens identified morphologically as $M$. helvolus (male or female) were also found to be M. angustifrons, and 5\% of specimens identified morphologically as female $M$. angustifrons were found to be M. helvolus (Table 3). The Coccophagus spp. had not previously been identified to species, but all four of the expected species were present, with almost half $(48 \%)$ identified as C. semicircularis 
Table 3 Molecular diagnosis of morphologically identified, alcohol preserved, adult parasitoid specimens using multiplex-PCR

\begin{tabular}{|c|c|c|c|c|c|}
\hline \multirow[t]{2}{*}{ Morphological ID } & \multicolumn{5}{|c|}{ Molecular ID } \\
\hline & M. helvolus & M. angustifrons & M. luteolus & M. stanleyi (swirskii) & No amplification $^{\mathrm{a}}$ \\
\hline M. helvolus female $(n=15)$ & 13 & 2 & - & - & - \\
\hline M. helvolus male $(n=60)$ & 47 & 5 & - & - & 8 \\
\hline M. stanleyi female $(n=46)$ & - & - & - & 45 & 1 \\
\hline M. stanleyi male $(n=46)$ & - & 29 & 1 & 16 & - \\
\hline M. luteolus female $(n=42)$ & - & - & 41 & - & 1 \\
\hline M. luteolus male $(n=19)$ & - & 3 & 16 & - & - \\
\hline \multirow[t]{2}{*}{ M. angustifrons female $(n=119)$} & 6 & 109 & - & 1 & 3 \\
\hline & C. cowperi & C. lycimnia & C. rusti & C. semicircularis & No amplification \\
\hline Coccophagus spp. $(n=77)$ & 11 & 11 & 18 & 37 & - \\
\hline
\end{tabular}

${ }^{a}$ Quality of the DNA extractions was subsequently tested using general 28S and ITS2 PCR primers (see text)

(Table 3). Of the 424 specimens tested using multiplex-PCR, only 13 failed to yield a PCR product. Of those, 12 also yielded nothing in conjunction with the universal $28 \mathrm{~S}$ and ITS2 primers and it is assumed that these represent failed DNA extractions. The $28 \mathrm{~S}$ and ITS2 regions of the remaining specimen (previously identified as a $M$. helvolus male) were sequenced (GenBank accessions HM856886 and HM856900, respectively), and the carcass was subsequently slidemounted and identified as Metaphycus alberti (Howard), an unexpected species that was not originally incorporated into the multiplex assays due to its lack of occurrence in previous field surveys.

The Metaphycus spp. multiplex-PCR detected M. luteolus in a total of seven of the ten brown soft scales from which DNA was extracted immediately or two days after exposure to the M. luteolus colony (i.e., before parasitism could be definitively assessed under a light microscope). All brown soft scales in which larvae or pupae could be seen prior to DNA extraction yielded a multiplex-PCR product of the expected size for the parasitoid species to which it had been exposed: M. luteolus, M. angustifrons or $M$. stanleyi (M. swirskii).

\section{Discussion}

Accurate identification of insect parasitoids used (or being considered for use) in biological control programs is a fundamental step in assessing their suitability and performance (Bigler et al. 2005;
Greenstone 2006). The taxon-specific multiplex-PCRs developed in the present study provide means by which any life stage of the major members of the complex of parasitoids attacking soft scales in California citrus groves (Lampson and Morse 1992; Bernal et al. 2001; Kapranas et al. 2007) can be accurately and rapidly identified. When coupled with a universal forward PCR primer, the genus-specific reverse primers yield a PCR product of a characteristic size that allows diagnosis of a specimen as Metaphycus spp., Coccophagus spp. or Microterys nietneri. Specimens identified as a Metaphycus spp. or Coccophagus spp. can then be identified to species using the respective species-specific multiplex-PCR. Since adults of these two genera are superficially easy to discriminate from one another, it may be possible to jump straight to one or other of the species-specific multiplex-PCRs for their identification. However, the two-step system potentially allows identification of immature life stages (eggs, larvae and pupae), even when extracted along with host scale DNA. In principal, we have demonstrated this using three Metaphycus spp. parasitizing brown soft scale. However, we cannot be certain this holds true for the remaining species, and it is also possible that a different host scale species may disrupt the PCR.

Tests of our multiplex-PCR protocols on fieldcollected material highlight the value of attaching a genetic signature to morphologically similar species (see also Rugman-Jones et al. 2009a, b). In the past, reliable identification of Metaphycus spp. has required well-prepared adult specimens that were 
normally sent to one of a small number of taxonomic experts familiar with these parasitoids (Guerrieri and Noyes 2000). Even in studies where an individual was expected to be one of only a small number of species, reliable species diagnosis involved rearing out adult parasitoids from individual scales in isolation, and subsequent identification based on differences in the color of the mummified host scale and/or association with females emerging from the same host (Kapranas et al. 2007). The present method provides a genetic profile for each species of interest, thereby removing the ambiguity from species identification, and allowing identification of any parasitoid life stage. Our entire protocol, from DNA extraction through to the completion of two consecutive rounds of multiplex-PCR and gel electrophoresis, can be performed in approximately $10 \mathrm{~h}$. We estimate that using our method, a single laboratory technician could readily diagnose specimens at a rate of 100 per day, and at a cost (in laboratory reagents and consumables) of around $\$ 1$ per specimen.

Multiplex-PCR can be an extremely efficient identification tool if a specimen is expected to be one of only a handful of species (Gariepy et al. 2008). However, herein lies a limitation of the multiplex-PCR method: it is context-specific and its initial design is dependent on having specimens to test that are representative of the spectrum of species one might later expect to encounter. For the purpose of our objectives (i.e., diagnosing species of Metaphycus and Coccophagus on California citrus), all of the major species identified in earlier survey work were included (Lampson and Morse 1992; Bernal et al. 2001; Kapranas et al. 2007). However, the occurrence of rare, unexpected, or recently introduced species may be overlooked, as was the case here in a single incidence of the unanticipated detection of $M$. alberti (discussed in more detail below). In some cases this is easily resolved; for example, with the deliberate introduction of new species (e.g., M. flavus), preemptive design and incorporation of additional species-specific primer(s) into the multiplex assay is possible and would allow one to monitor their establishment and success. In other instances, such as accidental introduction of additional species, it is difficult to predict how our multiplex assay would "respond" to the presence of an unknown species. It is likely that for such a specimen, the multiplex assay would fail to yield PCR product (or product of an unexpected size). In such cases, subsequent amplification and sequencing of the ITS2 and/or $28 \mathrm{~S}$ genes would at the very least provide a DNA sequence that could then be compared to known species. In addition, the use of the non-destructive EDNA HiSpEx ${ }^{\mathrm{TM}}$ Tissue Kit would allow for the recovery, mounting, and morphological identification of the voucher specimen associated with the genetic profile produced by DNA sequencing. As previously mentioned, this was the case for a single specimen of M. alberti among the 424 specimens used to challenge the validity of our multiplex assay. This not only demonstrates the specificity of our assay, but also provides guidelines for detecting rare or unexpected species that may occasionally occur in field-collected samples. In the case of $M$. alberti, this species was originally introduced to California from Australia in 1898, for the control of brown soft scale, and initially appeared to become established in the Riverside area. However, despite extensive sampling of brown soft scale in southern California, M. alberti was not detected after 1922, until it was "rediscovered" in 1997, attacking extremely low population densities of brown soft scale on English ivy Hedera helix L. (Stauffer and Rose 1997). It appears to be a very rare parasitoid of brown soft scale on citrus in California and therefore, not worthy of inclusion in our multiplex assay.

Application of our methodology to other geographic regions should be undertaken with care. Each multiplex-PCR has been designed to work within the constraints of a known degree of inter- and intraspecific genetic variation. In their survey of parasitoids attacking black scale on citrus and olives in Spain, Tena et al. (2008) were unable to differentiate between the larval stages of M. flavus and M. helvolus, and between those of $C$. lycimnia and $C$. semicircularis. Our method provides an accurate means of achieving this in California citrus groves, but it may be unwise to use it elsewhere without first surveying and sequencing the resident parasitoid fauna. Populations outside the geographic range of our study may differ sufficiently in their ITS2 sequence (on which the two species-specific multiplex-PCRs are based) such that they prevent annealing of the "correct" primer and/or facilitate annealing of an "incorrect" primer. This may result in the production of spurious PCR products and the potential for false positive identifications. 
The discovery that what has long been regarded as M. stanleyi in California citrus (Bernal et al. 1999, 2001; Kapranas et al. 2007), in fact appears to be $M$. swirskii, further highlights the difficulties that can be associated with interpreting morphological characters for the purpose of identification. No details are given about how species identity was determined when the UCR colony was originally collected (Bernal et al. 1999) but Kapranas et al. (2007) used morphological keys prepared by Annecke and Mynhardt (1971, 1972, 1981) to diagnose field-collected specimens as M. stanleyi (though their interpretation of these keys may have been influenced by what had been reported previously). In their revision of the European species of Metaphycus, Guerrieri and Noyes (2000) noted in their description of $M$. swirskii that it is very similar to $M$. stanleyi in general coloration and structure of the antennae, but "...can be separated from stanleyi on the basis of the colour of the genae, scape and wings". In their description of M. stanleyi they also suggested that "males of stanleyi are very similar to those of swirskii but can be separated by the less expanded scape. In stanleyi the male scape is about $2.5 \times$ as long as broad, whereas in swirskii it is slightly less than $2 \times$ as long as broad". Use of these characters to diagnose these species seems particularly surprising because, in the 'Introduction' to their revision (p. 151), Guerrieri and Noyes (2000) question the reliability of identification keys that rely on "the use of variable characters in order to separate species or groups of species, e.g., general body colouration, or very small differences in relative width of scape...", and note that several species "vary quite extensively in these characters (e.g. stagnarum), possibly as a result of ambient temperature experienced during development or some influence of the age or species of host or host's food plant". However, the same authors also indicated a strong stability in the color of the scape and of the gena following the examination of long series of the most common species, and as a consequence, these characters were used in their key to species. This raises some doubt over the validity of $M$. stanleyi and M. swirskii, which is exacerbated by the lack of a type specimen for M. stanleyi (Guerrieri and Noyes 2000), and by the fact that in at least one instance, Guerrieri and Noyes (2000) appear to include material from a single collection [ex star scale on coffee from Mchana, Kenya, x.1984 (A17534)] in their description of both species. To solve this problem, specimens that match the morphological description of M. stanleyi given by Guerrieri and Noyes (2000) will need to be collected and their DNA sequences compared with those of our M. swirskii specimens. It would also be interesting to determine whether the "M. stanleyi" that parasitizes black scale in California (Daane et al. 1991; Lampson and Morse 1992) is the same species.

While raising questions about the possible synonymy of $M$. stanleyi and $M$. swirskii, the sequence data provided herein also supports the validity of two other 'questionable' species, M. luteolus and $M$. flavus (Guerrieri and Noyes 2000). This will prove invaluable for accurately assessing the latter species as a potential biological control agent for the suppression of citricola scale and black scale in California citrus (Bernal et al. 1999, 2001; Schweizer et al. 2003). As reported by Guerrieri and Noyes (2000), it should be noted here that M. flavus and $M$. luteolus (both originally described from the USA) may still actually be synonymous, and that the species collected in Turkey and referred to herein as M. flavus, may represent a valid, undescribed species. Indeed, the true identity of these species may only be solved by the molecular and morphological determination of specimens of both sexes from a large number of localities, including the type locality of M. flavus in Florida.

The objective of this study was to create a quick, easy and above all, accurate, alternative to traditional morphology-based methods used to identify the major parasitoid species attacking soft scales in California citrus. The protocols developed herein provide significant reductions in the time, costs and expertise required to produce reliable species diagnoses. Furthermore, our multiplex-PCR methods allow the identification of both sexes and the immature life stages of each parasitoid species, even eggs inside a host scale. As such, our methodology could greatly improve efforts to monitor the success of augmentative releases of parasitoids (introduced from southern California) against citricola scale in the San Joaquin Valley.

Acknowledgments We thank Vladimir Berezovskiy (UCR) for slide-mounting specimens of Coccophagus spp., and both Jason Mottern (UCR) and Serguei Triapitsyn (UCR) for independently confirming their species identities. Apostolos Kapranas commented on an earlier version of this manuscript 
and kindly provided field-collected material used to test our methods. Jan Hare retrieved and sorted this field-collected material and Anthony Nguyen helped with the initial DNA work.

Open Access This article is distributed under the terms of the Creative Commons Attribution Noncommercial License which permits any noncommercial use, distribution, and reproduction in any medium, provided the original author(s) and source are credited.

\section{References}

Annecke DP, Mynhardt MJ (1971) The species of the zebratusgroup of Metaphycus Mercet (Hym., Encyrtidae) from South Africa, with notes on some extra-limital species. Rev Zool Bot Afr 83:322-360

Annecke DP, Mynhardt MJ (1972) The species of the insidiosus-group of Metaphycus Mercet in South Africa with notes on some extra-limital species (Hymenoptera: Encyrtidae). Rev Zool Bot Afr 85:227-274

Annecke DP, Mynhardt MJ (1981) The species of the asterolecanii-group of Metaphycus Mercet (Hymenoptera: Encyrtidae) from South Africa with notes on some extralimital species. J Entomol Soc South Afr 44:1-68

Bartlett BR (1953) Natural control of citricola scale in California. J Econ Entomol 46:25-28

Bartlett BR (1978) Coccidae. In: Clausen CP (ed) Introduced parasites and predators of arthropod pests and weeds: a world review. Agricultural Handbook 480. US Department of Agriculture, Washington, DC, pp 57-74

Benson DA, Karsch-Mizrachi I, Lipman DJ, Ostell J, Wheeler DL (2008) GenBank. Nucleic Acids Res 36:D25-D30

Bernal JS, Luck RF, Morse JG (1999) Augmentative release trials with Metaphycus spp. (Hymenoptera: Encyrtidae) against citricola scale (Homoptera: Coccidae) in California's San Joaquin Valley. J Econ Entomol 92:1099-1107

Bernal JS, Luck RF, Morse JG, Drury MS (2001) Seasonal and scale size relationships between citricola scale (Homoptera: Coccidae) and its parasitoid complex (Hymenoptera: Chalcidoidea) on San Joaquin Valley citrus. Biol Control 20:210-221

Bigler F, Bale JS, Cock MJW, Dreyer H, Greatrex R, Kuhlmann U, Loomans AJM, van Lenteren JC (2005) Guidelines for the importation and release of invertebrate biological control agents in European countries. BioControl News Inf $26: 15 \mathrm{~N}-123 \mathrm{~N}$

Campbell BC, Steffen-Campbell JD, Werren JH (1993) Phylogeny of the Nasonia species complex (Hymenoptera: Pteromalidae) inferred from an rDNA internal transcribed spacer (ITS2) and 28s rDNA sequences. Insect Mol Biol 2:225-237

Campbell B, Heraty JM, Rasplus JY, Chan K, Steffen-Campbell J, Babcock C (2000) Molecular systematics of the Chalcidoidea using 28s-D2 rDNA. In: Austin A, Dowton M (eds) The Hymenoptera: evolution, biodiversity and biological control. CSIRO Publishing, Victoria, Australia, pp 57-71
Compere H (1931) A revision of the species of Coccophagus a genus of Hymenopterous coccid-inhabiting parasites. Proc US Natl Mus 78:1-132

Compere H (1940) The African species of Metaphycus Mercet. Bull Entomol Res 31:7-33

Cornel AJ, Porter CH, Collins FH (1996) Polymerase chain reaction species diagnostic assay for Anopheles quadrimaculatus cryptic species (Diptera: Culicidae) based on ribosomal DNA ITS2 sequences. J Med Entomol 33: 109-116

Daane KM, Barzman MS, Kennett CE, Caltagirone LE (1991) Parasitoids of black scale in California: establishment of Prococcophagus probus Annecke \& Mynhardt and Coccophagus rusti Compere (Hymenoptera: Aphelinidae) in olive orchards. Pan-Pac Entomol 67:99-106

Fritz GN, Engman S, Rodriguez R, Wilkerson RC (2004) Identification of four vectors of human Plasmodium spp. by multiplex PCR: Anopheles rangeli, An. strode, An. triannulatus, and An. trinkae (Diptera: Culicidae: Nyssorhynchus). J Med Entomol 41:1111-1115

Gariepy TD, Kuhlmann U, Haye T, Gillott C, Erlandson M (2005) A single-step multiplex PCR assay for the detection of European Peristenus spp., parasitoids of Lygus spp. BioControl Sci Technol 15:481-495

Gariepy TD, Kuhlmann U, Gillott C, Erlandson M (2008) A large-scale comparison of conventional and molecular methods for the evaluation of host-parasitoid associations in non-target risk-assessment studies. J Appl Ecol 45: $708-715$

Grafton-Cardwell EE (1994) Resistance of California red scale and yellow scale in the San Joaquin Valley of California. Resist Pest Manag 6:7-9

Greenstone MH (2006) Molecular methods for assessing insect parasitism. Bull Entomol Res 96:1-13

Guerrieri E, Noyes JS (2000) Revision of European species of the genus Metaphycus Mercet (Hymenoptera: Chalcidoidea: Encyrtidae), parasitoids of scale insects (Homoptera: Coccoidea). Syst Entomol 25:147-222

Hall TA (1999) BioEdit: a user-friendly biological sequence alignment editor and analysis program for Windows 95/ 98/NT. Nucleic Acids Symp Ser 41:95-98

Kapranas A, Morse JG, Pacheco P, Forster LD, Luck RF (2007) Survey of brown soft scale Coccus hesperidum L. parasitoids in southern California citrus. Biol Control 42:288-299

Kennet CE (1988) Results of exploration for parasitoids of citricola scale, Coccus pseudomagnoliarum (Homoptera: Coccidae), in Japan and their introduction in California. Kontyu 56:445-457

Lampson LJ, Morse JG (1992) A survey of black scale, Saissetia oleae (Hom.: Coccidae) parasitoids (Hym.: Chalcidoidea) in southern California. Entomophaga 37: 373-390

Luck RF, Forster LD, Morse JG (1997) An ecologically based IPM program for citrus in California's San Joaquin Valley using augmentative biological control. Proc Int Soc Citric 1:499-503

Morse JG, Luck RF, Grafton-Cardwell EE (2006) The evolution of biologically-based integrated pest management on citrus in California. UC Plant Prot Q 17:1-11 
Quayle HJ (1938) Insects of citrus and other subtropical fruits. Comstock Press, Ithaca, NY

Rozen S, Skaletsky HJ (2000) Primer3 on the WWW for general users and for biologist programmers. In: Krawetz S, Misener S (eds) Bioinformatics methods and protocols: methods in molecular biology. Humana Press, Totowa, NJ, pp 365-386

Rugman-Jones PF, Hoddle MS, Mound LA, Stouthamer R (2006) Molecular identification key for the pest species of Scirtothrips (Thysanoptera: Thripidae). J Econ Entomol 99:1813-1819

Rugman-Jones PF, Wharton R, van Noort T, Stouthamer R (2009a) Molecular differentiation of the Psyttalia concolor (Szépligeti) species complex (Hymenoptera: Braconidae) associated with olive fly, Bactrocera oleae (Rossi) (Diptera: Tephritidae), in Africa. Biol Control 49:17-26

Rugman-Jones PF, Morse JG, Stouthamer R (2009b) Rapid molecular identification of armored scale insects (Hemiptera: Diaspididae) on Mexican 'Hass' avocado. J Econ Entomol 102:1948-1953

Schweizer H, Morse JG, Luck RF, Forster LD (2002) Augmentative releases of a parasitoid (Metaphycus sp. nr. flavus) against citricola scale (Coccus pseudomagnoliarum) on oranges in the San Joaquin Valley of California. Biol Control 24:153-166

Schweizer H, Morse JG, Luck RF (2003) Evaluation of Metaphycus spp. for suppression of black scale (Homoptera: Coccidae) on southern California citrus. Environ Entomol 32:377-386
Stauffer RS, Rose M (1997) Biological control of soft scale insects in interior plantscapes in the USA. In: Ben-Dov Y, Hodgson CJ (eds) Soft scale insects: their biology, natural enemies and control (World Crop Pests, volume 7B). Elsevier, Amsterdam, pp 183-205

Stouthamer R, Hu J, Van Kan FJPM, Platner GR, Pinto JD (1999) The utility of internally transcribed spacer 2 DNA sequences of the nuclear ribosomal gene for distinguishing sibling species of Trichogramma. BioControl 43:421-440

Tena A, Soto A, Garcia-Mari F (2008) Parasitoid complex of black scale Saissetia oleae on citrus and olives: parasitoid species composition and seasonal trend. BioControl 53:473-487

UCIPM Pest Management Guidelines (2009a) UC Pest Management Guidelines, citrus, California red scale and yellow scale. http://www.ipm.ucdavis.edu/PMG/r10730 1111.html

UCIPM Pest Management Guidelines (2009b) UC Pest Management Guidelines, citrus, citricola scale on citrus. http://www.ipm.ucdavis.edu/PMG/r107301511.html

White TJ, Burns T, Lee S, Taylor TJ (1990) Amplification and direct sequencing of fungal ribosomal RNA genes for phylogenetics. In: Innis MA, Gelfand DH, Sninsky JJ, White TJ (eds) PCR protocols: a guide to methods and applications. Academic, Burlington, MA, pp 315-322 